\title{
Optimization of Quercetin Extraction from Green Tea (Camellia sinensis) Using Central Composite Design, and the Pharmacological Activity of the Extract
}

\author{
I. M. Savic, ${ }^{\text {a, }}{ }^{,}$V. D. Nikolic, ${ }^{a}$ I. M. Savic-Gajic, ${ }^{a}$ Lj. B. Nikolic, ${ }^{a}$ K. Moder, ${ }^{b}$ and M. Hopkins ${ }^{c}$ \\ ${ }^{a}$ Faculty of Technology, University of Nis, Bulevar oslobodjenja 124,
}

16000 Leskovac, Serbia

bInstitute of Applied Statistics and Computing, Center of Experimental

doi: 10.15255/CABEQ.2015.2166

Design, Department of Landscape, Spatial and Infrastructure Sciences,

University of Natural Resources and Life Sciences, Austria

${ }^{c}$ Hopkins Research Ltd, Sevenoaks, United Kingdom

Original scientific paper

Received: January 11, 2015

Accepted: February 24, 2016

\begin{abstract}
The aim of this paper was to optimize an extraction procedure of quercetin from green tea using central composite design. Extraction time, ethanol concentration, and solid to liquid ratio were selected as the independent variables, while quercetin yield was defined as a response. The impact of factors and their interactions on the quercetin yield was studied based on the results of ANOVA test. The extraction time of $58.5 \mathrm{~min}$, ethanol concentration of $94.7 \%(\mathrm{v} / \mathrm{v})$, and solid to liquid ratio of $1: 19.4(\mathrm{~m} / \mathrm{v})$ were found as the optimal conditions. The experimental confirmation of the proposed optimal conditions indicated that there was a good agreement between the experimental and predicted values. In addition to quercetin, the presence of 17 bioactive compounds was confirmed in the green tea extract using mass spectrometry method. Antioxidant, antimicrobial and antitumor activity of the optimal extract was determined using DPPH assay, disk diffusion method, and MTT assay, respectively.
\end{abstract}

Key words:

optimization, quercetin extraction, green tea, central composite design, MS analysis

\section{Introduction}

Quercetin is one of the six subclasses of flavonoid compounds ${ }^{1}$, which has antioxidant properties ${ }^{2}$. Quercetin is found in many common foods including green tea ${ }^{1}$, apples, onions and berries ${ }^{3}$. Its structure with the indicated $\mathrm{C}$ atoms and rings is presented in Figure 1. Because of its interesting chemical and biological properties, quercetin has been one of the most studied flavonoids. Quercetin is a major bioflavonoid in the human diet ${ }^{4}$. Reactivity of phenolic compounds with free radical species and formation of considerably less reactive phenoxy radicals indicates the antioxidant activity of quercetin ${ }^{5}$.

The different methods of quercetin extraction, such as ultrasonic ${ }^{6,7}$, microwave-assisted ${ }^{8}$, solid-liquid extraction at ambient temperature ${ }^{9}$, and elevated pressure $^{10}$ supercritical extraction with carbon dioxide $^{11}$ from Bobgunnia madagascariensis, Caesalpiniaceae $^{12}$, Coriundrum sativum L. ${ }^{13}$, Abutilon indicum $^{14}$, Butea frondosa ${ }^{15}$, Petasites japonicus ${ }^{16}$, Euonymus alatus (Thunb.) Sieb. ${ }^{17}$, Citrus berga$\mathrm{mia}^{18}$ were described in the literature.

"Corresponding author: e-mail: ici_teh@yahoo.com; tel.: +381 16 247203; fax: +381 16242859

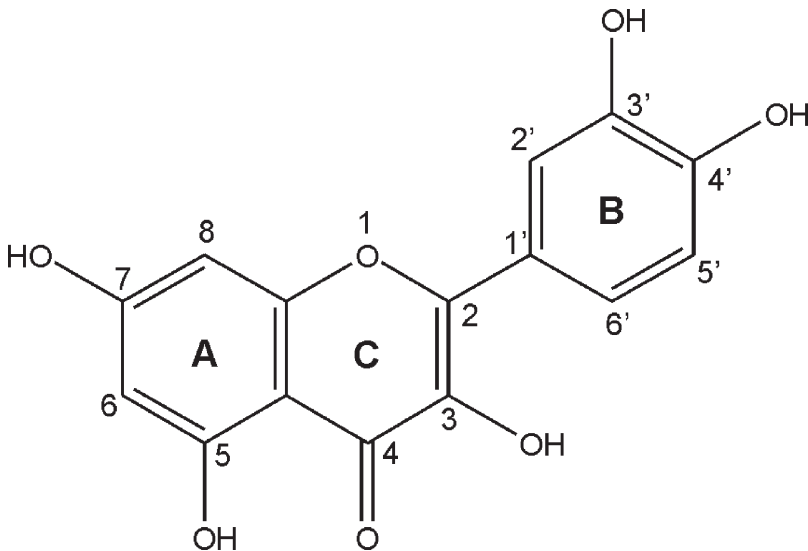

Fig. 1 - Quercetin structure with indicated C-atoms and rings

Solvents, such as chloroform ${ }^{12}$, methanol, ethanol $^{14}$ and acetone or mixtures of these and water are used for extraction ${ }^{19}$. For identification of the extracted quercetin, preparative TLC ${ }^{12}$, RP-HPLC ${ }^{11,13,14,20-22}$, micellar liquid chromatography ${ }^{23}$ and GC-MS ${ }^{24}$ were used.

A traditional approach, well known as the "One Variable At a Time" (OVAT), is commonly applied for investigation of the effects of extraction param- 
eters on the yield of the desired compounds. This approach follows the effect of one extraction parameter at a time on the extraction efficiency, while the impact of other parameters was omitted. Thus, the OVAT approach has a disadvantage, because it examines a narrow range of all possible combinations of variables, and as a result, the actual and detected optimum conditions are different in most cases. Its application impacts the quality of extraction results. The method of central composite design (CCD) is applied to overcome this problem and to combine the impact of a number of parameters on the yield of extraction. The identification of interacting variables has led to improvements in the efficiency of the extraction and in the quality of the extracted compounds. The main advantages of using experimental design compared with the traditional techniques are savings in money and time. This is especially important in the phase of process design when it is possible to estimate the combined effect of a number of variables with a small number of experiments by using a carefully chosen design. The identification of interactions between factors, as well as the effects of the variables themselves is possible by using this technique. This is important when the effect of one variable differs depending on the level of another variable, and when the knowledge about the process itself is limited. Modeling of extraction ${ }^{6,8,11,20}$, adsorption ${ }^{25-27}$, synthesis ${ }^{28}$ processes etc., using experimental design were commonly described in the literature. Thus, for instance, Pingret et al. ${ }^{29}$ optimized production of antioxidant-rich extracts from apple pomace using ultrasound-assisted extractions, while Chua et al. ${ }^{30}$ optimized the extraction conditions of phospholipids from palmpressed fiber. The effects of extraction time, $\mathrm{pH}$ of solution, and weight of the sample were studied to model and optimize a microwave-assisted natural dye extraction from pomegranate rind by Sinha et al. $^{31}$

The optimal conditions of quercetin extraction from some plant materials were estimated by using experimental design ${ }^{11,20}$. Green tea was acceptable as the plant material for the extraction study due to the significant amount of quercetin. Thus, the objective of this paper was to model and optimize the solid-liquid extraction of quercetin from green tea (Camellia sinensis) using CCD, because there are no data about extraction from this plant material in the literature. In this investigation, extraction time, ethanol concentration, and solid to liquid ratio were chosen as the independent variables. This study has an advantage over conventional extraction procedures, because valid data can be obtained based on a small number of experimental runs.

\section{Experimental}

\section{Reagents}

Quercetin (Merck Chemicals Ltd., Nottingham, United Kingdom), RPMI-1640 medium, dimethyl sulfoxide (DMSO), sodium dodecyl sulfate (SDS), 3-(4,5-dimethylthiazol-2-yl)-2,5-diphenyltetrazolium bromide (MTT), L-glutamine, penicillin, streptomycin, 2,2-diphenyl-1-picrylhydrazyl (Sigma Chemical Company, Saint Louis, USA), fetal bovin serum (FBS) (Gibco BRL, New York, USA), methanol HPLC grade (Merck, Darmstadt, Germany), formic acid purity $99 \%$ (Carlo Erba Reagents, Peypin, France), methanol LC-MS grade (Avantor Performance Materials, Inc., Deventer, Netherlands), $96 \%$ (v/v) ethanol (Zorka Pharma, Sabac, Serbia), and absolute ethanol (Alkaloid AD, Skopje, FYR Macedonia) were used as delivered.

\section{Carcinoma cell lines}

HeLa cells (human cervix adenocarcinoma cells), MDA-MB-361 and MDA-MB-453 cells (human breast adenocarcinoma), LS-174 cells (human colon carcinoma) and MRC-5 cells (human embryonic lung fibroblast).

\section{Plant material}

The green tea (Camellia sinensis) was purchased from AD Aleva (Novi Knezevac, Serbia). The plant material was dried to a moisture content of $6 \%$ at room temperature in a dark place. The samples were ground in a blender to produce a fine powder. The average particle size was $0.4 \mathrm{~mm}$.

\section{Extraction procedure of quercetin from green tea}

Extraction time, ethanol concentration, and solid to liquid ratio were used as process parameters. The values of these parameters were changed in order to study their effects on the extraction yield. In all cases, about $2 \mathrm{~g}$ of green tea powder was transferred into a $100-\mathrm{mL}$ flask and overflowed by different volumes of ethanol. The extractions were performed under reflux for the exactly defined time. The constant extraction temperature was maintained using boiling water bath. The extracts were evaporated under reduced pressure on a rotary evaporator after separation of the liquid phase by filtering. The samples were then dried to constant mass in a desiccator.

\section{Experimental design}

The most effective variables were chosen in order to plan the experiments according to CCD. CCD were applied to study the interactions between variables, as well as to derive a response surface that 
contains curvature with respect to the individual variables ${ }^{32}$. Three other advantages of CCD designs which were not used in this case, but which can be very useful in similar experimentation are:

The ability to firstly use an efficient and balanced screening design (perhaps with center points) to estimate linear effects along with some two-way interactions and other second-order effects. This means that the experimenter can effectively explore the variable space for indications of inflection points or other optima at first stage.

CCDs then allow the addition of star and center points sequentially around the screening design as an orthogonal block in a separate experiment, meaning that any change in the mean behavior between the two experiments will be cancelled out and the full second-order polynomial can be estimated accurately whatever the change.

CCDs also provide the ability to test for third-order lack-of-fit so that it is possible to discover if the second-order polynomial is an adequate predictor of the system being studied, and if not, e.g., how can the responses and/or variables be transformed non-linearly to make it possible.

The levels of CCD for the studied process parameters are presented in Table 1 .

Table 1 - Levels of independent variables for the CCD model

\begin{tabular}{l|c|c|c|c|c|c|c}
\hline \multirow{2}{*}{$\begin{array}{l}\text { Independent } \\
\text { variables }\end{array}$} & \multicolumn{3}{|c|}{ Symbol } & \multicolumn{6}{c}{ Levels } \\
\cline { 2 - 8 } & uncoded & coded & -1.68 & -1 & 0 & +1 & +1.68 \\
\hline time, min & $\tau$ & $X_{1}$ & 5.0 & 16.1 & 32.5 & 48.9 & 60.0 \\
$\begin{array}{l}\text { ethanol } \\
\text { concentration, } \\
\%\end{array}$ & $C_{e}$ & $X_{2}$ & 20.0 & 36.2 & 60.0 & 83.8 & 100.0 \\
$\begin{array}{l}\text { solid to liquid } \\
\text { ratio, } \mathrm{m} / \mathrm{v}\end{array}$ & $\omega$ & $X_{3}$ & $1: 10$ & $1: 16.1$ & $1: 25.0$ & $1: 33.91: 40.0$ \\
\hline
\end{tabular}

In the aim to define the impact of extraction parameters on the amount of extracted quercetin from green tea, the experimental runs were performed as presented in Table 2. The different experimental conditions of each experimental run are presented in this table. According to CCD, the number of experiments is expressed by $2 \mathrm{f}+2 \mathrm{f}+\mathrm{C}$, where $\mathrm{f}$ is the number of factors and $\mathrm{C}$ is the number of center points. In the present study, the values of $\mathrm{f}$ and $\mathrm{C}$ were 3 and 2, respectively, so that 16 experiments had to be conducted. The diagram of CCD generation for three factors (extraction time, solid-to-liquid ratio, ethanol concentration) is presented in Figure 2.

It is also important to ensure that the experimental runs are effectively randomized in order to ensure that any time trends commonly present in

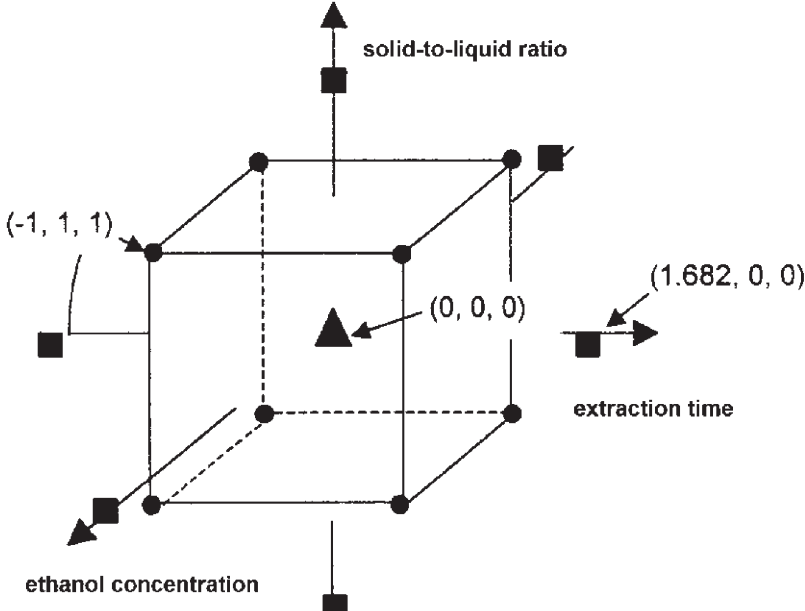

Fig. 2 - Generation of central composite design for three factors

Table 2 - Combination of extraction parameters with experimental and predicted values of response

\begin{tabular}{r|r|c|c|c|c}
\hline Run & $\begin{array}{c}\tau \\
\min \end{array}$ & $\begin{array}{c}C_{e} \\
\%\end{array}$ & $\begin{array}{c}\omega \\
(\mathrm{m} / \mathrm{V})\end{array}$ & $\begin{array}{c}Y_{\text {obs }} \\
(\mathrm{g} / 100 \mathrm{~g} \text { d.e. })\end{array}$ & $\begin{array}{c}Y_{\text {pred }} \\
(\mathrm{g} / 100 \mathrm{~g} \text { d.e. })\end{array}$ \\
\hline 1 & 5.0 & 60.0 & $1: 25.0$ & 0.210 & 0.247 \\
2 & 16.1 & 36.2 & $1: 16.1$ & 0.290 & 0.295 \\
3 & 16.1 & 36.2 & $1: 33.9$ & 0.330 & 0.295 \\
4 & 16.1 & 83.8 & $1: 16.1$ & 0.350 & 0.421 \\
5 & 16.1 & 83.8 & $1: 33.9$ & 0.590 & 0.421 \\
6 & 32.5 & 20.0 & $1: 25.0$ & 0.320 & 0.338 \\
7 & 32.5 & 60.0 & $1: 10.0$ & 0.310 & 0.341 \\
8 & 32.5 & 60.0 & $1: 25.0$ & 0.310 & 0.341 \\
9 & 32.5 & 60.0 & $1: 25.0$ & 0.290 & 0.341 \\
10 & 32.5 & 60.0 & $1: 40.0$ & 0.360 & 0.341 \\
11 & 32.5 & 100.0 & $1: 25.0$ & 0.810 & 0.908 \\
12 & 48.9 & 36.2 & $1: 16.1$ & 0.360 & 0.327 \\
13 & 48.9 & 36.2 & $1: 33.9$ & 0.360 & 0.327 \\
14 & 48.9 & 83.8 & $1: 16.1$ & 0.920 & 0.879 \\
15 & 48.9 & 83.8 & $1: 33.9$ & 0.970 & 0.879 \\
16 & 60.0 & 60.0 & $1: 25.0$ & 0.580 & 0.659 \\
\hline
\end{tabular}

$Y_{\text {obs }}$ - experimental value

$Y_{\text {pred }}$ - predicted value

the experimental systems are either completely excluded or at least significantly reduced with respect to the statistical model. Statistica 8.0 (Stat Soft, Inc., Tulsa, USA) software was used for modeling and optimization of this process.

StatSoft Statistica 8.0 provides four different occasions to approximate the mathematical model. Using these effects, it is possible to model the analyzed process in different ways. A linear main effect 
and linear main effect +2 ways give a linear model, while a linear-quadratic main effect and linear-quadratic effect +2 ways give a quadratic model. The main difference between the effects is in the interactions between process parameters. Thus, the different polynomial models were obtained by the use of these effects.

The obtained results for quercetin extraction from green tea were fitted by using a second-order polynomial equation. The full second-order polynomial equation can be defined in the following way (Eq. 1):

$$
\begin{aligned}
y= & a_{0}+a_{1} x_{1}+a_{2} x_{2}+a_{3} x_{3}+a_{11} x_{1}^{2}+a_{22} x_{2}^{2}+ \\
& +a_{33} x_{3}^{2}+a_{12} x_{1} x_{2}+a_{13} x_{1} x_{3}+a_{23} x_{2} x_{3}
\end{aligned}
$$

with $x_{1}, x_{2}, x_{3}$ - independent variables; $a_{0}$ - intercept; $a_{1}, a_{2}, a_{3}, a_{11}, a_{22}, a_{33}, a_{12}, a_{13}, a_{23}$ - regression coefficients, and $y$ - response function. The coefficients of second-order polynomial equation were estimated by least square regression. The three-dimensional and contour diagrams are commonly used for better presentation of the obtained data.

In order to confirm the ability of the proposed model to predict the yield of quercetin, the values of errors and correlation coefficients were calculated. Root mean square error (RMSE) was used as the error function. It can be calculated using the following formula (Eq. 2):

$$
R M S E=\sqrt{\frac{\sum\left(y_{i}^{p}-y_{i}^{m}\right)^{2}}{n}}
$$

with $y_{i}^{p}-$ desired output, $y_{i}^{m}-$ actual output, and $n$ - number of experimental runs.

Mean squared error (MSE) and mean absolute error (MAE) were used for further analysis of the obtained models. Also, the cross-validated correlation coefficient was used for estimation of the performance of models. Actually, MSE can be calculated using the following equation (Eq. 3):

$$
M S E=\frac{\sum\left(y_{i}^{p}-y_{i}^{m}\right)^{2}}{n}
$$

MAE presents a mean value of the absolute difference between the predicted and experimental values. It can be calculated in the following way (Eq. 4):

$$
M A E=\frac{\left|y_{i}^{p}-y_{i}^{m}\right|}{n}
$$

Leave-one-out is a commonly used form of cross-validation, where each data value is left out in turn, and a model is derived using the remainder of the data. The predictability is conventionally char- acterized by a cross-validated correlation coefficient $\left(Q^{2}\right)$. The cross-validated correlation coefficient is lower than the correlation coefficient $\left(r^{2}\right)$, and can have negative values. The cross-validated correlation coefficient is calculated in the following way (Eq. 5):

$$
Q^{2}=1-\frac{\sum_{i=1}^{n}\left(y_{i}^{m}-y_{i}^{p}\right)^{2}}{\sum_{i=1}^{n}\left(y_{i}^{p}-\bar{y}\right)^{2}}
$$

where $\bar{y}$ is the average observed value. A model is considered acceptable when the value of the cross-validated correlation coefficient is higher than 0.5 .

\section{HPLC analysis of the plant extracts}

The determination of quercetin content in the green tea extracts was performed using RP-HPLC method $^{33}$. The samples for RP-HPLC analysis were prepared by dissolving the dried plant extracts $(0.05 \mathrm{~g})$ in $5 \mathrm{~mL}$ of $6 \mathrm{~mol} \mathrm{~L}^{-1}$ hydrochloric acid and $5 \mathrm{~mL}$ of a mobile phase. The samples were sonificated for 15 minutes. Analysis was performed using methanol as a mobile phase with a flow rate of $1.0 \mathrm{~mL} \mathrm{~min}{ }^{-1}$. Before injecting into the column, the mobile phase and the analyzed samples were filtered through a $0.45 \mu \mathrm{m}$ millipore filter (Econofilters, Agilent Technologies, Germany). The injected volume of samples was $20 \mu \mathrm{L}$, while a detection wavelength was $370 \mathrm{~nm}$. The separation was carried out at $35^{\circ} \mathrm{C}$ using a ZORBAX Eclipse XDB-C $\mathrm{C}_{18}$ column $(4.6 \times 250 \mathrm{~mm}, 5 \mu \mathrm{m})$ Agilent Technologies, USA. Quercetin in the green tea extracts was identified based on the retention time of quercetin standard. In this study, Agilent 1100-Series HPLC system with DAD detector and Agilent 1100-Series autosampler was applied for this analysis. The peak areas were integrated automatically using the Agilent HPLC Data Analysis software.

\section{ESI-MS ${ }^{n}$ analysis of the optimal extract}

Mass spectroscopy (MS) method was applied in order to define the presence of other compounds in the extract obtained under optimal conditions of quercetin extraction. MS ion trap mass spectrometer (Thermo Scientific LTQ XL Linear Ion Trap Mass Spectrometer) was used with Xcalibur software for data acquisition and analysis. The sample was directed to a trap mass spectrometer with an electrospray interface (ESI). Mass spectra were obtained in both negative and positive modes with an ionsource voltage of $4.95 \mathrm{kV}$, a source current of $2.61 \mu \mathrm{A}$, a capillary temperature of $275^{\circ} \mathrm{C}$, a capillary voltage of $50 \mathrm{~V}$, a sheath gas pressure of 
137.14 KPa, and an auxiliary gas pressure of $13.93 \mathrm{KPa} . \mathrm{MS}^{2}$ spectrums of all compounds were obtained after effect of the different collision energies. The MS method was tuned using quercetin standard. The concentration of methanolic solutions of prepared samples was adjusted to $5 \mu \mathrm{g} \mathrm{cm} \mathrm{cm}^{-3}$ with the addition of formic acid in order to improve ionization of analyzed compounds.

\section{Determination of antioxidant activity (DPPH assay)}

A series of different concentrations was prepared from the stock solution of quercetin standard $\left(0.8 \mathrm{mg} \mathrm{cm}^{-3}\right)$ and from green tea extract $\left(2.0 \mathrm{mg} \mathrm{cm}^{-3}\right)$. The investigated samples $\left(2.5 \mathrm{~cm}^{3}\right)$ were treated with $1 \mathrm{~cm}^{3}$ of the ethanolic solution of DPPH $\left(3 \cdot 10^{-4} \mathrm{~mol} \mathrm{dm}^{-3}\right)$, and then incubated for $20 \mathrm{~min}-$ utes in the dark at room temperature. The absorbance of samples was measured in relation to $96 \%$ $(\mathrm{v} / \mathrm{v})$ ethanol at $517 \mathrm{~nm}$ and room temperature. The absorbance of DPPH solution obtained by dilution of the stock solution of DPPH $\left(1 \mathrm{~cm}^{3}\right)$ with ethanol $\left(2.5 \mathrm{~cm}^{3}\right)$ was determined under the same conditions. Varian Cary-100 Conc. Instrument and quartz cuvettes $(1 \times 1 \mathrm{~cm})$ were used during operation. The inhibition of DPPH radicals is calculated using the following equation (Eq. 6):

$$
\begin{gathered}
\text { inhibition of DPPH radicals }(\%)= \\
=\left(1-\frac{A_{S}-A_{B}}{A_{C}}\right) \cdot 100
\end{gathered}
$$

where are $A_{S}$ - absorbance of the samples (the samples treated by DPPH solution), $A_{B}$ - absorbance of blank (the diluted samples), $A_{C}-$ absorbance of the control solution (the diluted DPPH solution) ${ }^{34,35}$.

\section{Determination of antimicrobial activity}

Gram-negative bacteria (Escherichia coli ATCC 8739, Pseudomonas aeruginosa ATCC 9027), gram-positive bacteria (Bacillus subtilis ATCC 6633, Staphylococcus aureus ATCC 6539), and fungi (Candida albicans ATCC 10231, Aspergillus brasiliensis ATCC 16404) were used for investigation of antimicrobial activity of the extract obtained under optimal conditions. In this study, antibiotic agar $(\mathrm{pH}$ 6.5) and Sabouraud dextrose agar ( $\mathrm{pH} 5.6)$ were used for growth of bacteria and fungi, respectively. The warm and tempered medium was inoculated with the suspension of the investigated cells $(150 \mu \mathrm{L})$. The suspensions were prepared by dissolving the strains of the culture in the saline solution to the average content of $108 \mathrm{CFU} \mathrm{cm}^{-3}$. The sterile disks (Schleicher and Schuell, Dassel, Germany) with diameter of $12.5 \mathrm{~mm}$ were soaked with the ethanolic solutions of investigated samples
$(30 \mu \mathrm{L})$. The quercetin standard was prepared in the concentrations of $0.2,0.8$, and $1.6 \mathrm{mg} \mathrm{cm}^{-3}$, while the extract concentration was $2.0 \mathrm{mg} \mathrm{cm}^{-3}$. Ethanol was applied as a negative control. The antimicrobial activity of the extract was compared with gentamicin. The samples were treated under the same conditions in order to obtain the comparative results. Bacteria were incubated at $37{ }^{\circ} \mathrm{C}$ for $24 \mathrm{~h}$, while fungi were incubated at $25^{\circ} \mathrm{C}$ for $48 \mathrm{~h}$ under anaerobic conditions. The diameters of inhibition zones were obtained after averaging the values of three dishes.

\section{Determination of antitumor activity (MTT assay)}

Nutrition mediums

HeLa, LS-174, MRC-5 cell lines were maintained in the RPMI 1640 medium supplemented with $10 \%$ heat-inactivated fetal bovine serum (FBS) at $56{ }^{\circ} \mathrm{C}, 3 \mathrm{mmol} \mathrm{dm}^{-3}$ L-glutamine, $100 \mu \mathrm{g} \mathrm{cm}^{-3}$ streptomycin, $100 \mathrm{IU} \mathrm{cm}^{-3}$ penicillin, and $25 \mathrm{mmol} \mathrm{dm}^{-3}$ 4-(2-hydroxyethyl)-1-piperazineethanesulfonic acid (HEPES), and adjusted to pH 7.2 with bicarbonate solution. The same medium was used for MDA-MB-361 and MDA-MB-453 cell lines with the addition of $1.11 \mathrm{~g} \mathrm{~cm}^{-3}$ glucose.

\section{Treatment of the cell lines}

The samples were dissolved in DMSO to the concentration of $100 \mathrm{mg} \mathrm{cm}$. After that, the samples were diluted in the nutrition medium to the adequate concentrations. The cells were seeded into 96-well microtiter plates (Nunc, Nalgene, Denmark). The initial population density of HeLa cells, MDA-MB-361 cells, MDA-MB-453 cells, LS-174 cells and MRC-5 cells was 2,000 cells, 7,000 cells, 3,000 cells, 7,000 cells and 5,000 cells per well in $100 \mu \mathrm{L}$ medium, respectively. The nutrition medium was used as a blank sample. After twenty-four hours of seeding, the five different concentrations of investigated extract were added to $96-$ well plates. The final concentrations of the extract applied to target cells were 400, 200, 100, 50, and $25 \mu \mathrm{g} \mathrm{cm}{ }^{-3}$. Cells were grown in a humidified atmosphere of $5 \% \mathrm{CO}_{2}$ in air at $37^{\circ} \mathrm{C}$.

\section{Determination of cell survival}

The effect of the extract on the cancer cell survival was determined by the microculture tetrazolium test (MTT) according to Mosmann ${ }^{36}$ with modification by Ohno and $\mathrm{Abe}^{37} 72 \mathrm{~h}$ after addition of the compounds. After incubation, $20 \mu \mathrm{L}$ of MTT solution (5 $\mathrm{mg}$ MTT $\mathrm{cm}^{-3}$ PBS) was added to each well, and then another $100 \mu \mathrm{L}$ of SDS solution (10\%) was added after $4 \mathrm{~h}$. Absorbance was measured in ELISA reader at $570 \mathrm{~nm}$. Antiproliferative 
effect of the investigated quercetin standard and green tea extract was compared with a control group of malignant cells. The cancer cell survival is calculated in the following way (Eq. 7):

$$
S(\%)=\frac{A_{T}-A_{B}}{A_{C}-A_{B}} \cdot 100
$$

where are $A_{B}$ - absorbance of the blank, $A_{T}$ - absorbance of the treated cells, and $A_{C}-$ absorbance of the control. $\mathrm{IC}_{50}$ concentration is defined as the concentration of the substance that inhibits $50 \%$ of cell survival in comparison to the control panel.

\section{Results and discussion}

The extraction process plays a major role in the isolation of these bioactive compounds. There are several extraction techniques for isolation of compounds. The selection of extraction operating conditions requires experience. In this study, the technique under reflux was chosen for extraction of quercetin. After application of fractional factorial design, the significant variables (extraction time, ethanol concentration, solid to liquid ratio) were used for further optimization using CCD.

For describing the extraction procedure, a second-order polynomial equation was applied. As described below, $X_{3}$ was found to be inactive with respect to the quercetin response. This equation in terms of coded variables can be presented in the following way (Eq. 8):

$$
\begin{aligned}
& Y=0.341+0.123 X_{1}+0.040 X_{1}^{2}+ \\
& +0.169 X_{2}+0.100 X_{2}^{2}+0.106 X_{1} X_{2}
\end{aligned}
$$

In this equation, all significant terms are presented. The significance of equation terms was estimated using ANOVA test, and based on the Fisher distribution ( $F$-test) and $p$-value. The role of ANOVA test is to compare variation due to deviation from mean value. In Table 3, statistical results are presented. The mathematical relations for calculation of ANOVA test (SS, MS, $F$-value, $R^{2}, R_{\text {add }}^{2}$ ) are very often used in literature ${ }^{31,38}$. Correlation coefficient is 0.920 that indicates a solid performance of the proposed CCD model. This model is adequate, because Lack of Fit value was insignificant.

Pareto chart of the standardized effects can identify a factor and interaction effects, which are important in the process optimization study. It presents absolute values of effects and a reference line. The effects with values higher than the reference line can be observed as significant. From Figure 3, it can be concluded that the factors $X_{2}, X_{1}, X_{2}^{2}$ and interaction $X_{1} X_{2}$ are significant terms of the equation. All terms have positive effects on the response
Table 3 -ANOVA test for the CCD model

\begin{tabular}{l|c|c|c|c|c}
\hline & SS & df & MS & $F$ & $p$ \\
\hline (1)Var1 (L) & 0.204817 & 1 & 0.204817 & 29.58294 & 0.000285 \\
Var1 (Q) & 0.017613 & 1 & 0.017613 & 2.54399 & 0.141799 \\
(2)Var2 (L) & 0.392138 & 1 & 0.392138 & 56.63887 & 0.000020 \\
Var2 (Q) & 0.111629 & 1 & 0.111629 & 16.12324 & 0.002457 \\
1L by 2L & 0.090313 & 1 & 0.090313 & 13.04438 & 0.004755 \\
Lack of Fit & 0.069035 & 9 & 0.007671 & 38.353 & 0.124713 \\
Error & 0.069235 & 10 & 0.006923 & & \\
Pure Error & 0.000200 & 1 & 0.000200 & & \\
Total SS & 0.869400 & 15 & & & \\
\hline
\end{tabular}

Var 1 - extraction time

Var 2 - ethanol concentration

Var 3 - solid to liquid ratio

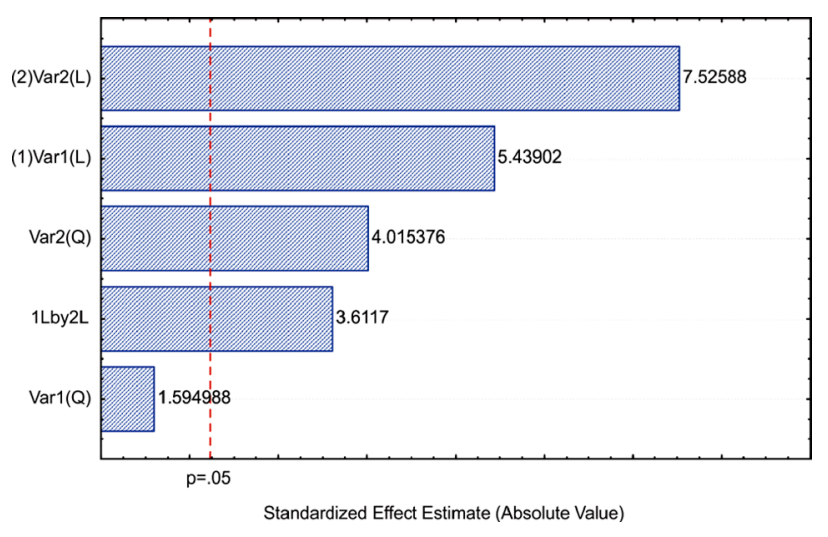

Fig. 3 - Pareto chart of standardized effect

of the model. The increase in any factor can lead to the increase in quercetin yield from tea. The impact of solid to liquid ratio was excluded from the equation. Therefore, this factor does not have a significant effect on the increase of quercetin amount in the extracts.

The equation with coded values was converted into the empirical equation with actual values. This polynomial equation can be presented in the following way (Eq. 9):

$$
\begin{gathered}
Y=0.341+0.245 \tau+0.079 \tau^{2}+ \\
+0.339 C_{e}+0.199 C_{e}^{2}+0.213 \tau C_{e}
\end{gathered}
$$

The functionalities between a quercetin yield and process variables are presented in Figures 4-6. The effect of extraction time and ethanol concentration on the quercetin yield at solid to liquid ratio of $1: 25(\mathrm{~m} / \mathrm{v})$ is presented in Figure 4. A strong interaction between these process parameters is clearly visible. These parameters almost have an equal contribution to increasing quercetin yield. A positive effect of extraction time on the amount of quercetin 


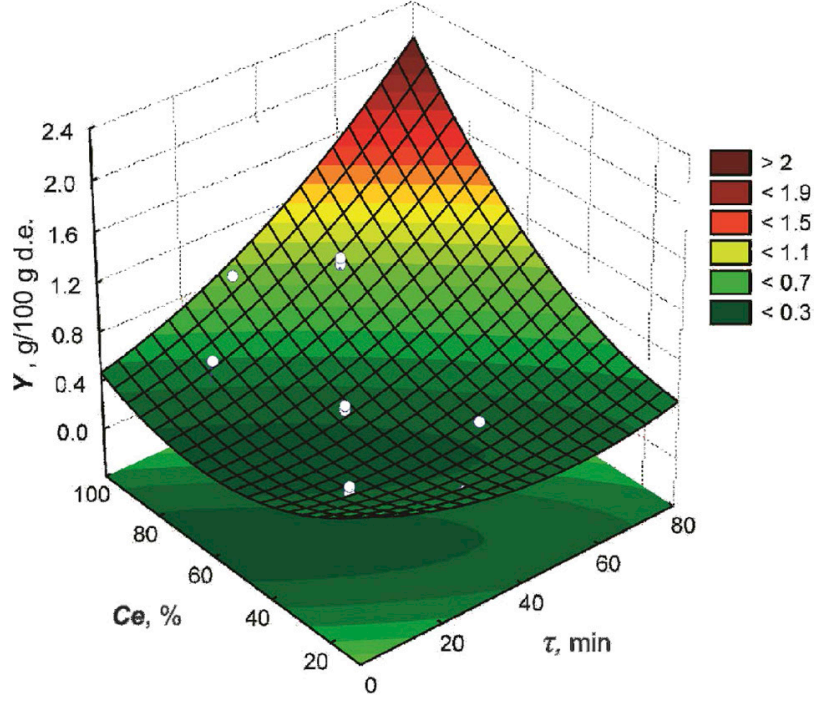

Fig. 4-Effect of extraction time and ethanol concentration on the quercetin yield for solid to liquid ratio of $1: 25(\mathrm{~m} / \mathrm{v})$

in the extract is noticed at higher ethanol concentrations, while at lower concentrations there is almost no effect. The change of ethanol concentration has a significant impact on the amount of quercetin in the extracts only after long extraction times. The increase in ethanol concentration also shows a positive effect on the observed response.

The interaction between the extraction time and solid to liquid ratio at the ethanol concentration of $60 \%(\mathrm{v} / \mathrm{v})$ for the proposed model is presented in Figure 5. The solid to liquid ratio had no significant effect on quercetin yield. The increase in extraction time increased the extraction yield.

The impact of ethanol concentration and solid to liquid ratio on the amount of quercetin at the ex-

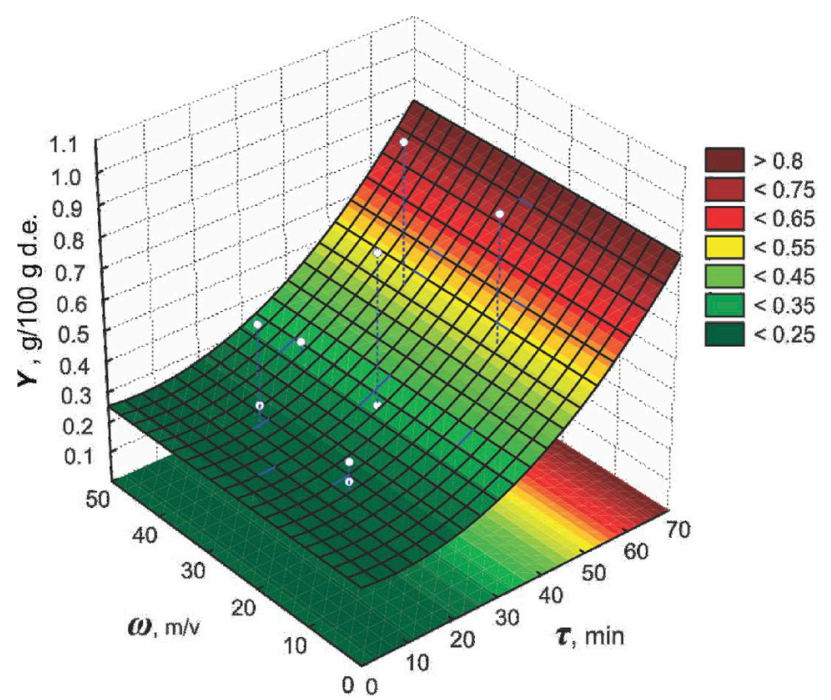

Fig. 5 - Effect of extraction time and solid to liquid ratio on the quercetin yield for ethanol concentration of $60 \%(v / v)$

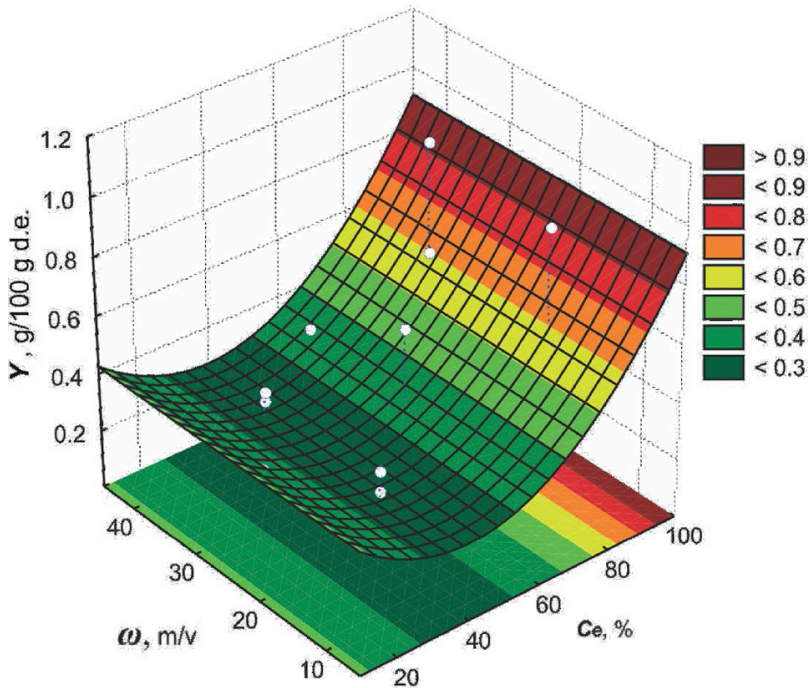

Fig. 6-Effect of ethanol concentration and solid to liquid ratio on the quercetin yield for extraction time of $32.5 \mathrm{~min}$

traction time of 32.5 minutes is presented in Figure 6 . The amount of quercetin does not change with increasing solid to liquid ratio. The graph indicates that ethanol concentration had a significant effect on the change in the quercetin amount in the extract. The quercetin yield significantly increased when the concentrations were higher than $80 \%$ $(\mathrm{v} / \mathrm{v})$. This was expected, because quercetin is a flavonoid poorly soluble in water, but better soluble in alcoholic solutions ${ }^{39}$

The calculated values of correlation coefficients $\left(R^{2}\right.$ and $\left.Q^{2}\right)$ are the same, and their values are 0.9204. Agreement of correlation coefficient and cross-validated correlation coefficient indicates the validity of the proposed model. RMSE, MSE and MAE are $0.0658,0.0043$ and 0.0525 , respectively. Even the largest error is still acceptable for the proposed model.

In Figure 7, a normal probability plot is presented. The normal probability plot is basically a plot of the ordered observations from a sample

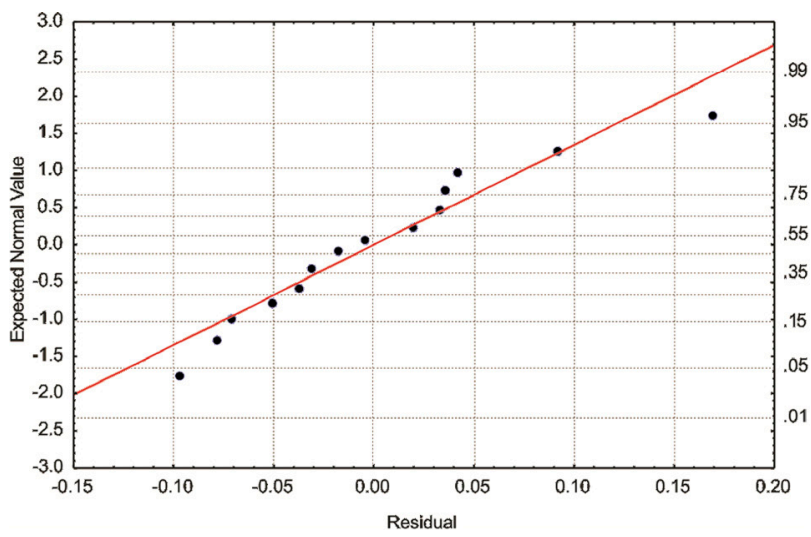

Fig. 7 - Normal probability plot of raw residuals 
against the corresponding percentage points from the standard normal distribution. Thus, the obtained plot indicates that the residuals follow a normal distribution, because the points follow a straight line with minimum deviations.

\section{Optimization of quercetin extraction}

The optimal conditions of quercetin extraction from green tea correspond with an extraction time of 58.5 minutes, an ethanol concentration of $94.7 \%$ $(\mathrm{v} / \mathrm{v})$, and a solid to liquid ratio of 1:19.4 $(\mathrm{m} / \mathrm{v})$ according to the numerical optimization. Under these conditions, the predicted value of quercetin yield is $1.34 \mathrm{~g} / 100 \mathrm{~g}$ d.e., while the experimental value is $1.36 \mathrm{~g} / 100 \mathrm{~g}$ d.e. Based on the experimental confirmation of the predicted value, the proposed optimal conditions can be accepted for quercetin extraction. Unlike the results of this research, a quercetin yield of $42.9 \mathrm{mg} / 100 \mathrm{~g}$ d.e. was obtained using supercritical $\mathrm{CO}_{2}$ extraction at a pressure of 392 bar, temperature of $50{ }^{\circ} \mathrm{C}$, and a static extraction time of 30 minutes, and a dynamic extraction time of 60 minutes from white "Vinho Verde" grape ${ }^{11}$. Dopico-Garcia et al. ${ }^{20}$ obtained a quercetin amount of
$0.95 \mathrm{mg} / 100 \mathrm{~g}$ d.e. using $5 \%$ methanol (pH 2) at a temperature of $40{ }^{\circ} \mathrm{C}$ from biomass Hypericum species. Thus, the advantages of our study are shorter extraction time, simpler extraction technique, and adequate choice of plant material for quercetin extraction.

\section{MS analysis}

In addition to quercetin, extraction of the bioactive compounds (gallic acid, (-)-gallocatechin, 3-O-caffeoylquinic acid, theobromine, 5-O-galloylquinic acid, $(+)$-catechin, caffeine, (-)-epigallocatechin-3-gallate, 4-p-coumaroylquinic acid, (-)-epicatechin-3-gallate, quercetin-3-O-rutinoside, quercetin-3-galactoside, kampferol-3-O-glucoside, apigenin glycoside, theaflavin-3,3'-digallate, thaflavin-3-gallate, kaempferol-rhamnose-hexose-rhamnose) was confirmed for optimal extraction conditions based on mass fragmentation patterns ${ }^{40-42}$. The mass spectral characteristics of the identified compounds in the optimal extract of green tea are presented in Table 4, and their structural formulas are given in Figure 8 .

Table 4 -Mass spectral characteristics of the identified compounds in the optimal extract of green tea

\begin{tabular}{|c|c|c|c|}
\hline Compounds & Collision energy $(\mathrm{eV})$ & {$[\mathrm{M}-\mathrm{H}]^{-}(\mathrm{m} / \mathrm{z})$} & $\mathrm{MS}^{2}(\mathrm{~m} / \mathrm{z})$ \\
\hline quercetin & 15 & 301 & $273,257,179,151$ \\
\hline gallic acid & 19 & 169 & 125 \\
\hline (-)-gallocatechin & 20 & 305 & $261,221,219,179,165,137,125$ \\
\hline 3-O-caffeoylquinic acid & 30 & 353 & $191,179,173,135$ \\
\hline theobromine & 16 & $181^{+}$ & $163,138,108$ \\
\hline 5-O-galloylquinic acid & 25 & 343 & 191,169 \\
\hline$(+)$-catechin & 20 & 289 & 245,205 \\
\hline caffeine & 24 & $195^{+}$ & 138,110 \\
\hline (-)-epigallocatechin-3-gallate & 20 & 457 & $331,305,169$ \\
\hline 4-p-coumaroylquinic acid & 30 & 337 & $191,173,163$ \\
\hline (-)-epicatechin-3-gallate & 25 & 441 & $331,289,169$ \\
\hline quercetin-3-O-rutinoside & 25 & 609 & 463,301 \\
\hline quercetin-3-galactoside & 20 & 463 & 301 \\
\hline kaempferol-3-O-glucoside & 23 & 447 & 285 \\
\hline apigenin glycoside & 22 & 563 & $503,473,443,353$ \\
\hline theaflavin-3,3'-digallate & 20 & 867 & $823,715,697,545,327$ \\
\hline theaflavin-3-gallate & 24 & 715 & $697,577,563,545,407$ \\
\hline kaempferol-rhamnose-hexose-rhamnose & 23 & 739 & $593,431,285$ \\
\hline
\end{tabular}

+ positive ion mode $[\mathrm{M}+\mathrm{H}]^{+}$ 
<smiles>O=C(O)c1cc(O)c(O)c(O)c1</smiles>

gallic acid<smiles>Oc1cc(O)c2c(c1)OC(c1cc(O)c(O)c(O)c1)C(O)C2</smiles>

(-)-gallocatechin<smiles>O=C(/C=C/c1ccc(O)c(O)c1)O[C@@H]1CC(O)(C(=O)O)C[C@@H](O)[C@@H]1O</smiles>

3-O-caffeoylquinic acid<smiles>Cn1cnc2c1c(=O)[nH]c(=O)n2C</smiles>

theobromine<smiles>O=C(/C=C/c1ccc(O)c(O)c1)O[C@@H]1C[C@](O)(C(=O)O)C[C@H](O)[C@H]1O</smiles>

5-O-galloylquinic acid<smiles>Cn1c(=O)c2c(ncn2C)n(C)c1=O</smiles>

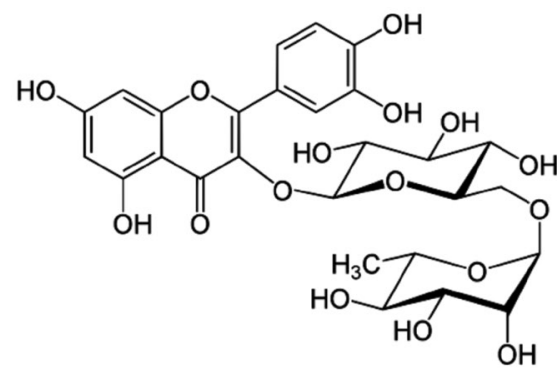

quercetin-3-O-rutinoside<smiles>O=C(O[C@H]1Cc2c(O)cc(O)cc2O[C@H]1c1cc(O)c(=O)c2c(O)c(O)cc([C@@H]3Oc4cc(O)cc(O)c4C[C@H]3O)c2c1)c1cc(O)c(O)c(O)c1</smiles>

theaflavin-3-gallate<smiles>O=C(O[C@H]1Cc2c(O)cc(O)cc2O[C@H]1c1cc(O)c(O)c(O)c1)c1cc(O)c(O)c(O)c1</smiles>

(-)-epigallocatechin-3-gallate<smiles>O=c1c(OC2OC3C(O)C(O)C(O)C(O)C3OC2O)c(-c2ccc(O)c(O)c2)oc2cc(O)cc(O)c12</smiles>

quercetin-3-O-galactoside<smiles>O=C(O)OC1CC(O)(C(=O)O)CC(O)[C@H]1O</smiles><smiles>O=C(O[C@H]1Cc2c(O)cc(O)cc2O[C@H]1c1ccc(O)c(O)c1)c1cc(O)c(O)c(O)c1</smiles>

$\mathrm{HO}$<smiles>Oc1ccc([C@@H]2Oc3cc(I)cc(O)c3C[C@H]2O)cc1O</smiles>

$(+)$-catechin

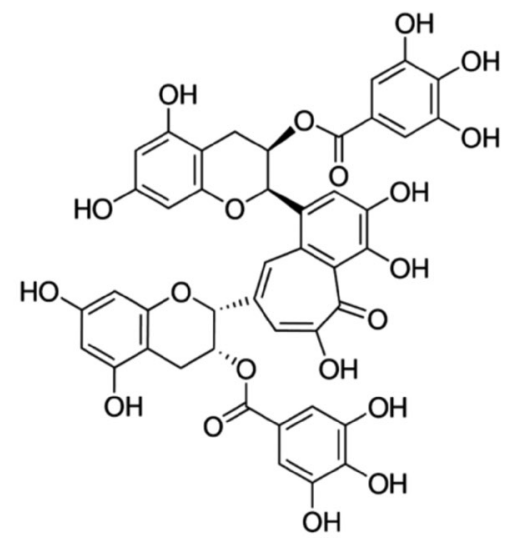

theaflavin-3,3'-digallate apigenin glycoside<smiles>O=c1cc(-c2ccc(O)cc2)oc2cc(OC3OCC4(O)C(O)OC3C(O)C4O)cc(O)c12</smiles>

(-)-epicatechin-3-gallate<smiles>O=c1c(OC2C(O)OC(CO)C(O)C(O)C2O)c(-c2ccc(O)cc2)oc2cc(O)cc(O)c12</smiles>

kaempferol-3-O-glucoside

Fig. 8 -Ingredients identified in the optimal extract of green tea 


\section{Antioxidant activity of quercetin and green tea extract}

Quercetin belongs to the group of bioflavonoids with the strongest antioxidant activity. Three functional groups present in the quercetin structure are responsible for its ability to "scavenge" DPPH radicals. Among these groups are (1) the ortho-catechol group in the B ring with high stability of formation of the radicals, (2) the conjugation in B ring with 4-oxo group and 2,3-double bond, which provides the delocalization of electrons from $\mathrm{B}$ ring, and (3) the 3- and 5-OH groups with 4-oxo group, which allow delocalization of the electrons from 4-oxo group to both substituents (Figure 1). These functional groups provide higher delocalization of electrons and higher stability to the aroxyl radicals.

In this paper, DPPH assay was applied for determination of antioxidant activity of the standard and green tea extract due to availability of DPPH reagent and accuracy of the method. The ability of quercetin standard and extract to scavenge free DPPH radicals is presented graphically in Figure 9.

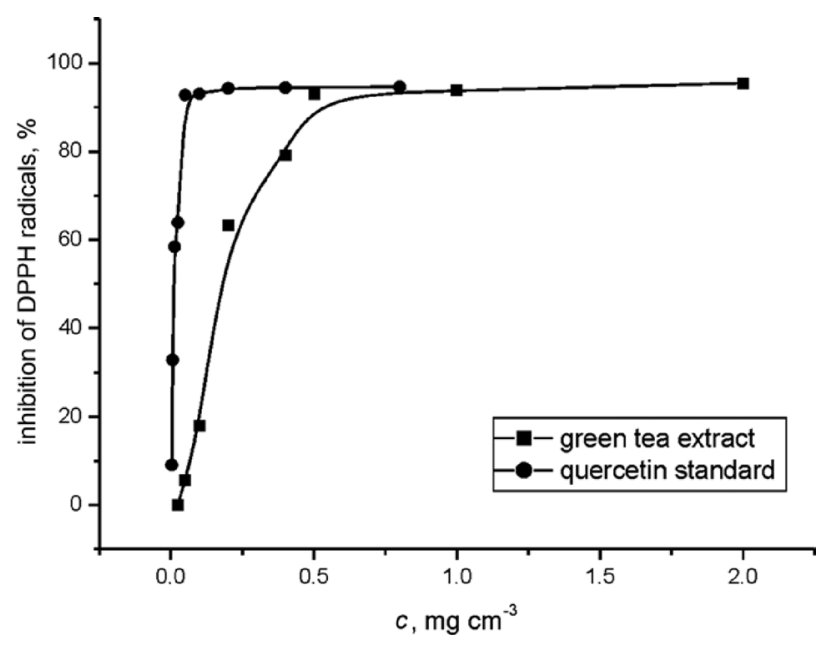

Fig. 9 - Antioxidant activity of quercetin and tea extract

The increase in quercetin concentration $(0.003$ $\left.-0.800 \mathrm{mg} \mathrm{cm}^{-3}\right)$, i.e. green tea extract concentration $\left(0.031-2.000 \mathrm{mg} \mathrm{cm}^{-3}\right)$ causes an increase in the inhibition of DPPH radicals. The highest values of inhibition of DPPH radicals for quercetin standard $(92.83 \%)$ and green tea extract $(92.99 \%)$ were achieved at 0.05 and $0.5 \mathrm{mg} \mathrm{cm}^{-3}$, respectively. The calculated $\mathrm{EC}_{50}$ value for quercetin standard $\left(\mathrm{EC}_{50}=10.4 \mathrm{mg} \mathrm{cm}^{-3}\right)$ is lower than the values for the extract $\left.\left(\mathrm{EC}_{50}=106.6 \mathrm{mg} \mathrm{cm}\right)^{-3}\right)$. These results indicate that quercetin has a better antioxidant activity than the extract. This is expected due to different antioxidant capacity of the compounds in the extract.
Yimilaz et al. ${ }^{43}$ investigated the antioxidant activity of catechin, epicatechin and gallic acid by ORAC method. They found that the activity decreases from catechin, epicatechin to gallic acid. Stewart et al. ${ }^{44}$ estimated the antioxidant potential of catechin, 3-O-caffeoylquinic acid, flavonols and theaflavins. Using the trolox equivalent antioxidant capacity (TEAC) method, it is confirmed that about $30 \%$ of the green tea activity originates from (-)-epigallocatechin-3-gallate. Theaflavins retain the antioxidant capacity similar to monomers of (-)-epicatechin, while the conjugated flavonols have insignificant antioxidant activity. Seeram et al. ${ }^{45}$ confirmed the antioxidant activity of catechin and caffeine using the ORAC and TEAC methods. In addition, caffeine and its metabolic products, such as theobromine and xanthine, show antioxidant properties ${ }^{46}$. Ioku and collaborators ${ }^{47}$ confirmed that quercetin and its monoglucoside have also an antioxidant activity.

\section{Antimicrobial activity of quercetin and green tea extract}

The antimicrobial activity of the extract and quercetin was investigated using the disk diffusion method. Ethanol $(96 \%, \mathrm{v} / \mathrm{v})$ was used for control in order to analyze the effect of this solvent on microbial growth, while gentamicin was used as the referent sample. Based on the obtained results (Table 5), it can be seen that the fungi strains $C$. albicans and A. brasiliensis) remain resistant to the effect of standard, extract, antibiotic, and solvent. The inhibitory activity of antibiotic was not only noticed on

Table 5-Antimicrobial activity of quercetin standard, green tea, and the solvent

\begin{tabular}{|c|c|c|c|c|c|c|}
\hline \multirow{2}{*}{$\begin{array}{c}\text { Micro- } \\
\text { organism }\end{array}$} & \multicolumn{3}{|c|}{ Quercetin standard } & \multirow{2}{*}{\begin{tabular}{c|} 
Green tea \\
extract
\end{tabular}} & \multirow{2}{*}{$\begin{array}{c}\text { Genta- } \\
\text { micin }\end{array}$} & \multirow{2}{*}{ Ethanol } \\
\hline & $\mathrm{C} 1$ & $\mathrm{C} 2$ & $\mathrm{C} 3$ & & & \\
\hline $\begin{array}{l}\text { E. coli } \\
\text { ATCC } 8739\end{array}$ & ++ & +++ & ++++ & +++ & ++ & - \\
\hline $\begin{array}{l}\text { P. aeruginosa } \\
\text { ATCC } 9027\end{array}$ & + & ++ & ++ & ++ & - & - \\
\hline $\begin{array}{l}\text { B. subtilis } \\
\text { ATCC } 6633\end{array}$ & - & - & - & + & +++ & - \\
\hline $\begin{array}{l}\text { S. aureus } \\
\text { ATCC } 6539\end{array}$ & ++ & ++ & +++ & ++ & ++ & - \\
\hline $\begin{array}{l}\text { C. albicans } \\
\text { ATCC } 10231\end{array}$ & - & - & - & - & - & - \\
\hline $\begin{array}{l}\text { A. brasiliensis } \\
\text { ATCC } 16404\end{array}$ & - & - & - & - & - & - \\
\hline
\end{tabular}

Without antimicrobial activity (-), inhibition zone $<15 \mathrm{~mm}$. Weak antimicrobial activity $(+)$, inhibition zone of $15-16 \mathrm{~mm}$. Moderate antimicrobial activity $(++)$, inhibition zone of $17-19 \mathrm{~mm}$. High antimicrobial activity $(+++)$, inhibition zone of $20-22 \mathrm{~mm}$. Strong antimicrobial activity $(++++)$, inhibition zone $>23 \mathrm{~mm}$. The standard deviation of $\pm 0.5 \mathrm{~mm}$. 
the strain of $P$. aeruginosa. The quercetin standard at the concentration of $1.6 \mathrm{mg} \mathrm{cm}^{-3}$ had the highest antimicrobial activity on the strain of E. coli compared with the extract. The green tea extract and quercetin showed approximately the same activity in bacteria $P$. aeruginosa. The inhibition of $B$. subtilis growth was only noticed in the case of green tea extract and antibiotic. S. aureus remained resistant against ethanol. The quercetin concentration of $1.6 \mathrm{mg} \mathrm{cm}^{-3}$ showed the highest activity.

For the compounds identified in the green tea extract obtained under optimal conditions using the MS method, the data confirm that they have antimicrobial activity. The studies showed that gallocatechins and their derivates are directly responsible for antibacterial activity of green tea extract ${ }^{48}$. Polyphenols, especially (-)-epigallocatechin-3-gallate and (-)-epicatechin-3-gallate have a broad spectrum of action on gram-positive and gram-negative bacteria. Friedman et al. ${ }^{49}$ investigated the antimicrobial action of theaflavin. They noticed that alkaloids (caffeine and theobromine) have the ability to affect pathogenic microorganisms including insects, bacteria, fungi, and viruses ${ }^{50}$.

\section{In vitro antitumor activity of quercetin and green tea extract}

Tumor cell lines (MDA-MB-361, MDAMB-453, HeLa, LS-174) were treated with different concentrations of quercetin standard and green tea extract in order to investigate antiproliferative effects. The colorimetric method based on the use of tetrazolium salt was applied for this study. The concentration of samples that inhibit the growth and survival of human tumor cell lines are presented in Table 6 . These results were compared with the results obtained for the healthy MRC-5 cells.

It was noticed that quercetin and green tea extract have cytotoxic activity on the estrogen-dependent (MDA-MB-361) and estrogen-independent (MDA-MB-453) breast cancer cell lines. The green tea extract has shown activity on the HeLa and LS-174 cancer cell lines at concentrations of $47.41 \pm 0.03$ and $78.12 \pm 0.02 \mu \mathrm{g} \mathrm{cm}^{-3}$, respectively. In this case, the quercetin concentration that showed activity was $44.07 \pm 0.34 \mu \mathrm{g} \mathrm{cm}^{-3}$ in HeLa cells, and $24.28 \pm 1.31 \mu \mathrm{mol} \mathrm{dm}{ }^{-3}$ in LS-174 cells. Unlike the antiproliferative activity of quercetin, the activity of extract was higher in HeLa cancer cells than in human colon cancer cells. The effect of green tea extract and quercetin was not noticed in MRC-5 cancer cells at concentrations lower than $200 \mu \mathrm{g} \mathrm{cm}^{-3}$, i.e. $60 \mu \mathrm{g} \mathrm{cm}^{-3}$, respectively.

\section{Conclusion}

In this study, the extraction procedure of quercetin from green tea was investigated, modeled, and optimized by using CCD. The obtained experimental data were fitted by a reduced second-order polynomial equation that excluded the inactive variable completely. Optimal conditions were achieved using a numerical optimization. The extraction time of 58.5 minutes, the ethanol concentration of $94.7 \%$ $(\mathrm{v} / \mathrm{v})$, and the solid to liquid ratio of 1:19.4 $(\mathrm{m} / \mathrm{v})$ were selected as the optimal conditions. A good agreement between experimental and predicted values at these conditions indicates that the model is adequately designed. Using this procedure, the amount of extracted quercetin is higher than with other described procedures. In addition to quercetin, the other seventeen compounds were identified in the optimal extract of green tea using MS analysis. The identified compounds in the extract belong to the polyphenolic compounds and purine alkaloids. The values of inhibition of DPPH radicals for quercetin and green tea extract are over $90 \%$, indicating a very high antioxidant activity. The extract and quercetin showed antimicrobial activity against the strains of $E$. coli, $P$. aeruginosa and $S$. aureus. The highest anti-proliferative activity was noticed for quercetin on the human breast cancer cell line (MDA-MB-361), while the lowest activity was noticed for green tea extract on the same tumor cell line. Based on the anti-proliferative results, the extract and quercetin can be used for tumor treatment without damage to healthy cells.

\section{ACKNOWLEDGMENTS}

This work was supported by the Ministry of Education, Science and Technological Development of the Republic of Serbia under the project TRp-34012.

Table $6-I C_{50}$ values of quercetin standard and green tea extract

\begin{tabular}{l|c|c|c|c|c}
\hline \multicolumn{1}{c}{ Compound } & MDA-MB-361 & MDA-MB-453 & HeLa & LS-174 & MRC-5 \\
\hline \multicolumn{7}{c}{$\mathrm{IC}_{50}\left(\mu \mathrm{g} \mathrm{cm}^{-3}\right)$} \\
green tea extract & $114.39 \pm 0.13$ & $95.48 \pm 2.53$ & $47.41 \pm 0.03$ & $78.12 \pm 0.02$ & $>200$ \\
quercetin & $19.24 \pm 0.06$ & $28.83 \pm 1.05$ & $44.07 \pm 0.34$ & $24.28 \pm 1.31$ & $>60$ \\
\hline
\end{tabular}

$\mathrm{IC}_{50}$ values were expressed as the mean \pm SD determined from the results of MTT assay in three independent experiments. 


\section{Conflict of interest}

The authors declare that they have no conflict of interest.

This article contains no studies with human or animal subjects.

\section{References}

1. Kelly, G. S., Quercetin, Altern. Med. Rev. 16 (2011) 172.

2. Pinelo, M., Manzocco, L., José Nuñez, M., Cristina Nicoli, $M$., Solvent effect on quercetin antioxidant capacity, Food Chem. 88 (2004) 201. doi: http://dx.doi.org/10.1016/j.foodchem.2004.01.034

3. Ramadan, M. F., Antioxidant characteristics of phenolipids (quercetin-enriched lecithin) in lipid matrices, Ind. Crop. Prod. 36 (2012) 363.

doi: http://dx.doi.org/10.1016/j.indcrop.2011.10.008

4. Erlund, I., Freese, R., Marniemi, J., Hakala, P., Alfthan, G., Bioavailability of quercetin from berries and the diet, Nutr. Cancer 54 (2006) 13. doi: http://dx.doi.org/10.1207/s15327914nc5401_3

5. Di Majo, D., La Neve, L., La Guardia, M., Casuccio, A., Giammanco, M., The influence of two different $\mathrm{pH}$ levels on the antioxidant properties of flavonols, flavan-3-ols, phenolic acids and aldehyde compounds analysed in synthetic wine and in a phosphate buffer, J. Food Compos. Anal. 24 (2011) 265. doi: http://dx.doi.org/10.1016/j.jfca.2010.09.013

6. Huang, W., Xue, A., Niu, H., Jia, Z., Wang, J., Optimised ultrasonic-assisted extraction of flavonoids from Folium eucommiae and evaluation of antioxidant activity in multitest systems in vitro, Food Chem. 114 (2009) 1147. doi: http://dx.doi.org/10.1016/j.foodchem.2008.10.079

7. Vasantha Rupasinghe, H. P., Kathirvel, P., Huber, G. M., Ultrasonication-assisted solvent extraction of quercetin glycosides from 'Idared'apple peels, Molecules 16 (2011) 9783.

doi: http://dx.doi.org/10.3390/molecules16129783

8. Careri, M., Corradini, C., Elviri, L., Mangia, A., Optimization of a rapid microwave assisted extraction method for the liquid chromatography-electrospray-tandem mass spectrometry determination of isoflavonoid aglycones in soybeans, J. Chromatogr. A 1152 (2007) 274.

doi: http://dx.doi.org/10.1016/j.chroma.2007.03.112

9. Braga, L. R., Rosa, A. A., Dias, A. C. B., Synthesis and characterization of molecularly imprinted silica mediated by $\mathrm{Al}$ for solid phase extraction of quercetin in Ginkgo biloba L, Anal. Methods-UK 6 (2014) 4029. doi: http://dx.doi.org/10.1039/c4ay00471j

10. Zgórka, G., Pressurized liquid extraction versus other extraction techniques in micropreparative isolation of pharmacologically active isoflavones from Trifolium L. species, Talanta 79 (2009) 46. doi: http://dx.doi.org/10.1016/j.talanta.2009.03.011

11. Dimitrieska-Stojković, E., Zdravkovski, Z., Supercritical fluid extraction of quercetin and rutin from Hyperici herba, J. Liq. Chromatogr. R. T. 26 (2003) 2517. doi: http://dx.doi.org/10.1081/JLC-120023798

12. Adeyemi, M. M., Adebote, D. A., Amupitan, J. O., Oyewale, A. O., Agbaji, A. S., Antifeedant activity of quercetin isolated from the stem bark of Bobgunnia madagascariensis (Desv.) J.H.Kirkbr \& Wiersema. (Caesalpiniaceae), Aust. J. Basic Appl. Sci. 4 (2010) 3342.
13. Hadjmohammadi, M., Sharifi, V., Investigation of optimum extraction conditions for determination of quercetin and kaempferol in Coriander (Coriundrum sativum L.) by using experimental design and HPLC, J. Food Drug Anal. 17 (2009) 293.

14. Rajalakshmi, P. V., Senthil, K. K., Direct HPLC analysis of quercetin in exudates of Abutilon indicum (Linn). Malvaceae, J. Pharm. Sci. Technol. 1 (2009) 80.

15. Dutta, N. K., Mazumdar, K., Mishra, U. S., Dastidar, S. G., Park, J. H., Isolation and identification of a flavone (quercetin) from Butea frondosa bark, Pharm. Chem. J. 41 (2007) 269. doi: http://dx.doi.org/10.1007/s11094-007-0059-5

16. Matsuura, H., Amano, M., Kawabata, J., Mizutani, J., Isolation and measurement of quercetin glucosides in flower buds of Japanese butterbur (Petasites japonicus subsp. Gigantea Kitam.), Biosci. Biotech. Bioch. 66 (2002) 1571. doi: http://dx.doi.org/10.1271/bbb.66.1571

17. Zhang, F., Yang, Y., Su, P., Guo, Z., Microwave-assisted extraction of rutin and quercetin from the stalks of Euonymus alatus (Thunb.) Sieb, Phytochem. Analysis 20 (2009) 33. doi: http://dx.doi.org/10.1002/pca.1088

18. Calabro, M. L., Galtieri, V., Cutroneo, P., Tommasini, S., Ficarra, P., Ficarra, R., Study of the extraction procedure by experimental design and validation of a LC method for determination of flavonoids in Citrus bergamia juice, J. Pharm. Biomed. Anal. 35 (2004) 349. doi: http://dx.doi.org/10.1016/S0731-7085(03)00585-5

19. Naczk, M., Shahidi, F., Extraction and analysis of phenolics in food, J. Chromatogr. A 1054 (2004) 95. doi: http://dx.doi.org/10.1016/S0021-9673(04)01409-8

20. Dopico-García, M. S., Valentao, P., Guerra, L., Andrade, P. B., Seabra, R. M., Experimental design for extraction and quantification of phenolic compounds and organic acids in white "Vinho Verde" grapes, Anal. Chim. Acta 583 (2007) 15 . doi: http://dx.doi.org/10.1016/j.aca.2006.09.056

21. Careri, M., Corradini, C., Elviri, L., Nicoletti, I., Zagnoni, I., Direct HPLC analysis of quercetin and trans-resveratrol in red wine, grape, and winemaking byproducts, J. Agric. Food Chem. 51 (2003) 5226. doi: http://dx.doi.org/10.1021/jf034149g

22. Phani, Ch. R. S., Vinaykumar, Ch., Umamaheswararao, K., Sindhuja, G., Quantitative analysis of quercetin in natural sources by RP-HPLC, Int. J. Res. Pharm. Biomed. Sci. 1 (2010) 19.

23. Hadjmohammadi, M., Nazari, S., Separation optimization of quercetin, hesperetin and chrysin in honey by micellar liquid chromatography and experimental design, J. Sep. Sci. 33 (2010) 3144. doi: http://dx.doi.org/10.1002/jssc.201000326

24. Tokussoğlu, Ö., Ünal, M. K., Yıldırım, Z., HPLC-UV and GC-MS characterization of the flavonol aglycons quercetin, kaempferol, and myricetin in tomato pastes and other tomato-based products, Acta Chromatogr. 13 (2003) 196.

25. Savic, I. M., Stojiljkovic, S. T., Stojanovic, S. B., Moder, K., Modeling and optimization of $\mathrm{Fe}$ (III) adsorption from water using bentonite clay: comparison of central composite design and artificial neural network, Chem. Eng. Technol. 35 (2012) 2007. doi: http://dx.doi.org/10.1002/ceat.201200085

26. Turan, N. G., Mesci, B., Ozgonenel, O., Artificial neural network (ANN) approach for modeling Zn (II) adsorption from leachate using a new biosorbent, Chem. Eng. J. 173 (2011) 98 . doi: http://dx.doi.org/10.1016/j.cej.2011.07.042 
27. Turan, N. G., Mesci, B., Ozgonenel, O., The use of artificial neural networks (ANN) for modeling of adsorption of $\mathrm{Cu}$ (II) from industrial leachate by pumice, Chem. Eng. J. 171 (2011) 1091. doi: http://dx.doi.org/10.1016/j.cej.2011.05.005

28. Cruz-Díaz, M., Buchaly, C., Kreis, P., Pérez-Cisneros, E. S., Lobo-Oehmichen, R., Górak, A., Synthesis of $n$-propyl propionate in a pilot-plant reactive distillation column: Experimental study and simulation, Comput. Chem. Eng. 39 (2012) 118 doi: http://dx.doi.org/10.1016/j.compchemeng.2012.01.004

29. Pingret, D., Fabiano-Tixier, A. S., Bourvellec, C. L., Renard, C. M., Chemat, F., Lab and pilot-scale ultrasound-assisted water extraction of polyphenols from apple pomace, J. Food Eng. 111 (2012) 73. doi: http://dx.doi.org/10.1016/j.jfoodeng.2012.01.026

30. Chua, S. C., Tan, C. P., Mirhosseini, H., Lai, O. M., Long, K., Baharin, B. S., Optimization of ultrasound extraction condition of phospholipids from palm-pressed fiber, J. Food Eng. 92 (2009) 403. doi: http://dx.doi.org/10.1016/j.jfoodeng.2008.12.013

31. Sinha, K., Saha, P. D., Datta, S., Response surface optimization and artificial neural network modeling of microwave assisted natural dye extraction from pomegranate rind, Ind. Crop. Prod. 37 (2012) 408. doi: http://dx.doi.org/10.1016/j.indcrop.2011.12.032

32. Box, G. E., Draper, N. R., Empirical model-building and response surfaces, John Wiley \& Sons, New York, 1987.

33. Savic, I. M., Nikolic, V. D., Savic, I. M., Nikolic, Lj. B., Stankovic, M. Z., Development and validation of a new RP-HPLC method for determination of quercetin in green tea, J. Anal. Chem. 68 (2013) 906. doi: http://dx.doi.org/10.1134/S1061934813100080

34. Aquino, R., Morelli, S., Tomaino, A., Pellegrino, M., Saija, A., Grumetto, L., Puglia, C., Ventura, D., Bonina, F., Antioxidant and photoprotective activity of a crude extract of Culcitium reflexum $H B K$. leaves and their major flavonoids, J. Ethnopharmacol. 79 (2002) 183. doi: http://dx.doi.org/10.1016/S0378-8741(01)00379-8

35. Choi, C. W., Kim, S. C., Hwang, S. S., Choi, B. K., Ahn, H. J., Lee, M. Y., Park, S. H., Kim, S. H., Antioxidant activity and free radical scavenging capacity between Korean medicinal plants and flavonoids by assay-guided comparison, Plant. Sci. 163 (2002) 1161. doi: http://dx.doi.org/10.1016/S0168-9452(02)00332-1

36. Mosmann, T., Rapid colorimetric assay for cellular growth and survival: application to proliferation and cytotoxicity assays, J. Immunol. Methods. 65 (1983) 55. doi: http://dx.doi.org/10.1016/0022-1759(83)90303-4

37. Ohno, M., Abe, T., Rapid colorimetric assay for the quantification of leukemia inhibitory factor (LIF) and interleukin-6 (IL-6), J. Immunol. Methods 145 (1991) 199. doi: http://dx.doi.org/10.1016/0022-1759(91)90327-C

38. Marchitan, N., Cojocaru, C., Mereuta, A., Duca, G., Cretescu, I., Gonta, M., Modeling and optimization of tartaric acid reactive extraction from aqueous solutions: A comparison between response surface methodology and artificial neural network, Sep. Purif. Technol. 75 (2010) 273. doi: http://dx.doi.org/10.1016/j.seppur.2010.08.016

39. Razmara, R. S., Daneshfar, A., Sahraei, R., Solubility of quercetin in water+ methanol and water+ ethanol from (292.8 to 333.8) K, J. Chem. Eng. Data 55 (2010) 3934. doi: http://dx.doi.org/10.1021/je9010757

40. Savić, I., Nikolić, V., Savić, I., Nikolić, Lj., Jović, M., Jović, $M$., The qualitative analysis of the green tea extract using ESI-MS method, Advanced Technologies 3 (2014) 30.

41. Dou, J., Lee, V. S., Tzen, J. T., Lee, M. R., Identification and comparison of phenolic compounds in the preparation of oolong tea manufactured by semifermentation and drying processes, J. Agr. Food Chem. 55 (2007) 7462. doi: http://dx.doi.org/10.1021/jf0718603

42. Del Rio, D., Stewart, A. J., Mullen, W., Burns, J., Lean, M. E., Brighenti, F., Crozier, A., HPLC-MS ${ }^{\mathrm{n}}$ analysis of phenolic compounds and purine alkaloids in green and black tea, J. Agr. Food Chem. 52 (2004) 2807. doi: http://dx.doi.org/10.1021/jf0354848

43. Yilmaz, Y., Toledo, R. T., Major flavonoids in grape seeds and skins: antioxidant capacity of catechin, epicatechin, and gallic acid, J. Agr. Food Chem. 52 (2004) 255. doi: http://dx.doi.org/10.1021/jf030117h

44. Stewart, A. J., Mullen, W., Crozier, A., On-line high-performance liquid chromatography analysis of the antioxidant activity of phenolic compounds in green and black tea, Mol. Nutr. Food Res. 49 (2005) 52. doi: http://dx.doi.org/10.1002/mnfr.200400064

45. Seeram, N. P., Henning, S. M., Niu, Y., Lee, R., Scheuller, H. S., Heber, D., Catechin and caffeine content of green tea dietary supplements and correlation with antioxidant capacity, J. Agr. Food Chem. 54 (2006) 1599. doi: http://dx.doi.org/10.1021/jf052857r

46. Azam, S., Hadi, N., Khan, N. U., Hadi, S. M., Antioxidant and prooxidant properties of caffeine, theobromine and xanthine, Med. Sci. Monit. 9 (2003) 325

47. Ioku, K., Tsushida, T., Takei, Y., Nakatani, N., Terao, J., Antioxidative activity of quercetin and quercetin monoglucosides in solution and phospholipid bilayers, BBA-Biomembranes 1234 (1995) 99. doi: http://dx.doi.org/10.1016/0005-2736(94)00262-N

48. Taylor, P. W., Hamilton-Miller, J. M., Stapleton, P. D., Antimicrobial properties of green tea catechins, Food Sci. Technol. Bull. 2 (2005) 71. doi: http://dx.doi.org/10.1616/1476-2137.14184

49. Friedman, M., Henika, P. R., Levin, C. E., Mandrell, R. E., Kozukue, N., Antimicrobial activities of tea catechins and theaflavins and tea extracts against Bacillus cereus, J. Food Protect. 69 (2006) 354

50. Friedman, M., Overview of antibacterial, antitoxin, antiviral, and antifungal activities of tea flavonoids and teas, Mol. Nutr. Food Res. 51 (2007) 116. doi: http://dx.doi.org/10.1002/mnfr.200600173 